\title{
The Influence of Organizational Justice on Intention to Leave: Examining the Mediating Role of Organizational Commitment and Job Satisfaction
}

\author{
Mohammad Hani Al-Kilani ${ }^{1}$ \\ ${ }^{1}$ Department of Business Administration, Al-Hussein Bin Talal University, Jordan \\ Correspondence: Dr. Mohammad Hani Al-Kilani, Assistant Professor of Organization Theory, Department of \\ Business Administration, Al-Hussein Bin Talal University, Jordan.
}

Received: November 21, 2016

Accepted: December 5, 2016

Online Published: February 3, 2017

doi:10.5430/jms.v8n1p18

URL: http://dx.doi.org/10.5430/jms.v8n1p18

\begin{abstract}
The current study was conducted on the employees of a Jordanian governmental department that has 240 employees, using a questionnaire. The number of the returned questionnaires was 150 , achieving response rate of $62.5 \%$. The influences of organizational justice, organizational commitment and job satisfaction on employees' intention to leave their job were scrutinized and were supported. The mediating roles of organizational commitment and job satisfaction in the relationship between organizational justice and intention to leave were investigated and corroborated. As previous research supported the relations between the studied variables, the contribution of this study is the suggested and corroborated conceivable succession for the effects of the precursors of employees' intentions to leave their jobs, which demonstrate its significance. The implications and limitations of this study are presented.
\end{abstract}

Keywords: intention to leave, distributive justice, procedural justice, interactional justice, job satisfaction, organizational commitment, Jordan

\section{Introduction}

A number of researchers studied employees' intentions to leave their job, implying a voluntary intended action; to predict the actual turnover rates. Nonetheless, the presence of intentions to leave exemplifies a potential threat to the organizations that epitomize employees' work places. Several antecedents of turnover were addressed by researchers suggesting that controlling these antecedents can alleviate the potential threat imposed by turnover rates. This study addresses several antecedents of employees' intentions to leave and scrutinizes mediating roles amongst these predecessors. The mediating roles suggest the sequence of these antecedents, hence, identifying the stages for monitoring and controlling these antecedents.

Literature supports the influence of employees' perceived organizational justice, job satisfaction, and organizational commitment; on their intentions to voluntary leave their jobs. Simultaneously, the corroboration of the impact of organizational justice on both job satisfaction and organizational commitment is also palpable in the literature. These evidences suggest the mediating roles for both job satisfaction and organizational commitment between organizational justice and intention to leave.

Further, this study was conducted on public employees embracing permanent and annual contracted ones. Hence, their organization is amongst the non-profit group, where employment is opened through the civil service bureau, and objective selection criteria are applied.

\section{Literature Review}

\subsection{Organizational Justice}

As an important aspect of employees' work related perception, researchers (e.g., Byrne and Cropanzano, 2001) acquiesce that organizational justice was first coined by Greenberg (1987). Organizational justice refers to justice in the workplace (Greenberg, 1990) and the psychology of fairness in organizational context (Byrne and Cropanzano, 2001). 
Literature apropos organizational justice alit to four aspects of justice: distributive, procedural, interpersonal, and informational, where the last two can be subsumed in interactional justice (Nowakowski and Conlon, 2005). Although some researchers considered informational justice individually, several researchers considered the three-facet construct of organizational justice that embraces: distributive, procedural, and interactional (e.g. Cheng, 2014; Hassan \& Hashim, 2011; Nakra, 2014; Schappe, 1998; Sia \& Tan, 2016; Xerri, 2014), which is adopted in this study.

Distributive justice, the first studied justice construct (Nowakowski and Conlon, 2005), refers to fairness of outcomes/rewards when compared to inputs/costs (Adams, 1965; Deutsch, 1975; Homans, 1961). There are three states of distributive justice prepositioned by Adams (1965). The first state is equality, where outcomes equal inputs. The second state is positive inequality, where outcomes exceed inputs. The third state is negative inequality, where inputs exceed outcomes. Further, outcomes can be either positive/favorable or negative/unfavorable (Homans, 1961).

Procedural Justice was presented by Thibaut and Walker (1975), and refers to justice of the procedures that yielded the outcomes (Bies and Shapiro, 1988; Brockner and Siegel, 1996; Folger and Cropanzano, 1998; Folger and Greenberg, 1985). Leventhal (1980) propositioned six procedural justice rules: consistency, bias-suppression, accuracy, correctability, representativeness, and ethicality; claiming that an individual's perception of procedural justice is based on the existence of these rules.

Interactional justice was introduced by Bies and Moag (1986), which refers to judging the attribute of an interactive demeanor a person receives while performing organizational procedures. Bies and Moag (1986) discerned six characteristics that whittle the judgments of interactional justice: honesty, avoiding deception, courtesy, respect for individual rights, and propriety of behavior, and justifying decisions. The first five characteristics are aspects of treatment while the last one belongs to explanation.

\subsection{Organizational Commitment}

Organizational commitment refers to an employee's wish to stay with the organization as a result of its characteristics (Cook and Wall, 1980; Porter et. al., 1974), which reflects his/her affective attachment to its goals and values (Buchanan II, 1974). There are three components of organizational commitment (Buchanan II, 1974; Porter $e t$ al., 1974): identification, involvement, and loyalty.

Allen and Meyer (1990) extricated three types of organizational commitment: affective, continuance, and normative. Allen and Meyer (1990) acknowledged that affective commitment is demonstrated by the work of Porter et al. (1974), which explains why an employee wants to stay with the organization, while the other two types explain the need and the obligation to stay, respectively. In this study organizational commitment refers to affective commitment according to Allen and Meyer (1990).

\subsection{Job Satisfaction}

Job satisfaction is the demonstration of an employee's feelings towards his/her job as a result of evaluating its characteristics (Agho et al., 1992; Locke, 1976). The two main types of measure for this construct are: global job satisfaction, and satisfaction with several facets of the job (Taber and Alliger, 1995). The term 'global job satisfaction' is used to refer to the attitude about the job as a whole (Taber and Alliger, 1995). In this study job satisfaction refers to the global job satisfaction.

\subsection{Antecedents of Intention to Leave}

The importance of studying employee' intentions to leave their jobs engendered from the significance of sustaining employees' retention. Several antecedents of intention to leave were studied throughout research, nonetheless; this study focuses on organizational justice, job satisfaction, and organizational commitment. Further, although the relations between the studied variables were supported in numerous studies, this study focuses on key studies to clarify the trends of these relations.

The influence of perceived organizational justice and its three facets is supported in a number of studies that pertain to various contexts. Several studies reported significant negative influence for distributive justice (e.g. Basar and Sigri, 2015; Hassan \& Hashim, 2011), procedural justice (e.g. Basar and Sigri, 2015; Hassan \& Hashim, 2011), and interactional justice (e.g. Basar and Sigri, 2015) on employees' intentions to leave their jobs.

Further, organizational commitment implies employees' wishes to stay with their organization; hence, it is expected to influence their intentions to leave their job. The significant negative influence of employees' organizational commitment on their intentions to leave their jobs is unclouded through a number of relevant studies (e.g. Das et al., 2013; Hassan \& Hashim, 2011; Yurchisin \& Park, 2010). Furthermore, employees' who experience satisfaction with 
their jobs are expected to retain their jobs. Analogously, the significant negative influence of employees' job satisfaction on their intentions to leave their jobs is evident (e.g. Carcia-Chas et al., 2014; Das et al., 2013; Hassan \& Hashim, 2011; Hussein et al., 2014; Yurchisin \& Park, 2010)

Furthermore, as the three facets of organizational justice pertain to employees' perception about their organization and the variate aspects of their jobs, the former variables are expected to influence the latter ones, i.e. employees' organizational commitment and job satisfaction. A number of studies supported the significant positive influences of distributive justice (e.g. Cheng, 2014; Hassan \& Hashim, 2011; Nakra, 2014), procedural justice (e.g. Cheng, 2014; Nakra, 2014), and interactional justice (e.g. Cheng, 2014; Hassan \& Hashim, 2011; Nakra, 2014) on organizational commitment. Similarly, a number of studies supported the significant positive influences of distributive justice (e.g. Schappe, 1998), procedural justice (e.g. Hassan \& Hashim, 2011; Schappe, 1998; Xerri, 2014), and interactional justice (e.g. Schappe, 1998; Xerri, 2014) on job satisfaction.

These relationships are demonstrated in Figure 1. The reported significant influences of these antecedents suggest the existence of plausible mediating roles for both organizational commitment and job satisfaction. There was no evidence that these suggested mediators were examined by previous research especially in a similar context, which can lay bare the significance of this study. Hence, the following hypotheses are contrived:

H1: Employees' organizational commitment mediates the relationship between their perception of distributive justice and their intentions to leave their jobs.

H2: Employees' organizational commitment mediates the relationship between their perception of procedural justice and their intentions to leave their jobs.

H3: Employees' organizational commitment mediates the relationship between their perception of interactional justice and their intentions to leave their jobs.

H4: Employees' job satisfaction mediates the relationship between their perception of distributive justice and their intentions to leave their jobs.

H5: Employees' job satisfaction mediates the relationship between their perception of procedural justice and their intentions to leave their jobs.

H6: Employees' job satisfaction mediates the relationship between their perception of interactional justice and their intentions to leave their jobs.

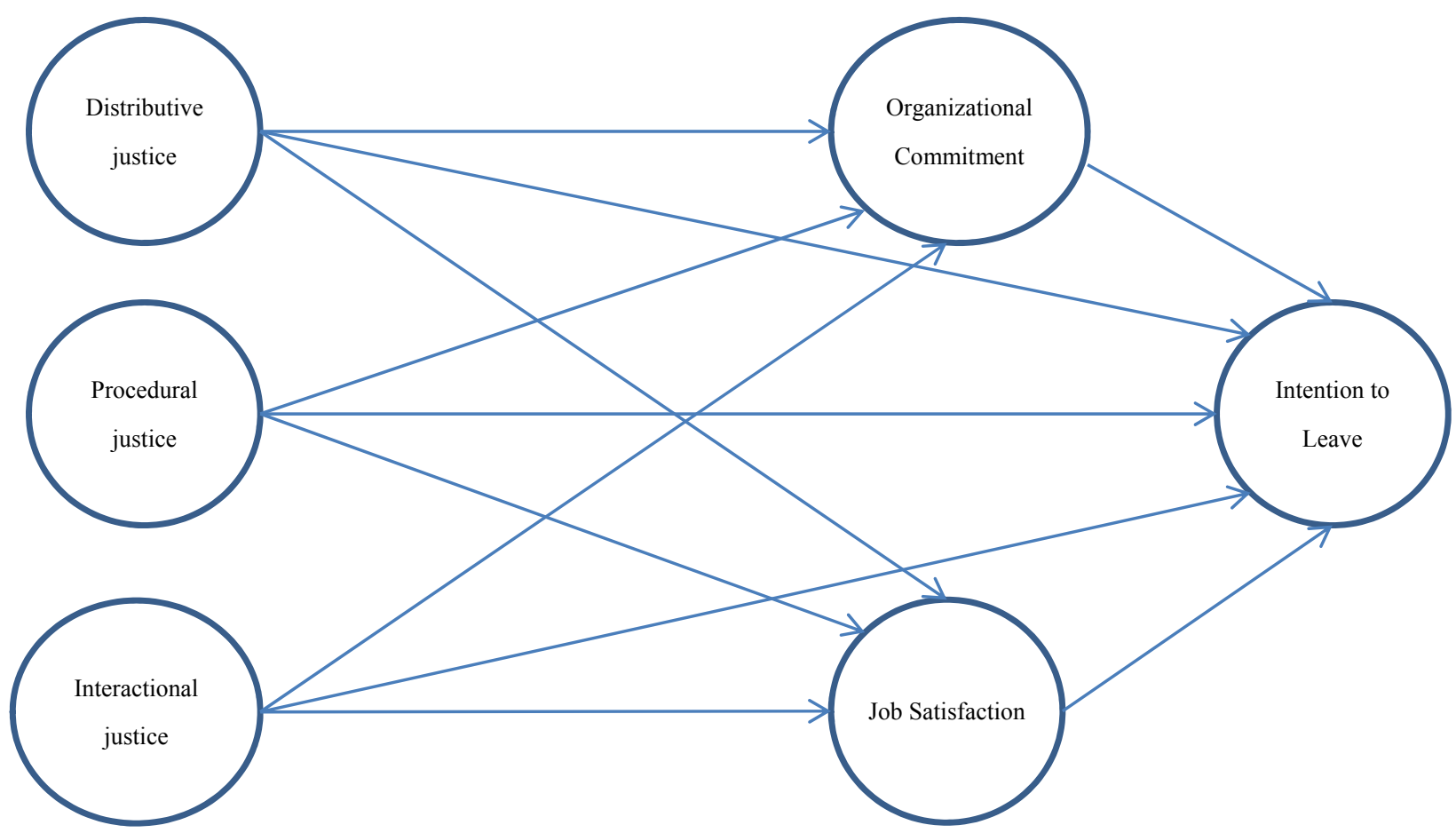

Figure 1. The relationships between the variables 


\section{Method}

\subsection{Population and Sampling}

This research was conducted on the employees of one Jordanian governmental department located in Amman that has 200 permanent employees and 40 employees assigned with annual contracts, where all employees were targeted. The returned questionnaires were 150 with response rate of $62.5 \%$.

\subsection{Scale Measurement}

\subsubsection{Intention to Leave Job}

This variable was assessed via a single-item scale as practiced by several researchers (e.g. Hussein et al., 2014; Velde \& Feij, 1995). Respondent were asked if they intend to leave their current job. Their responses were assessed by a five-point Likert scale ranging from (1) Strongly disagree to (5) Strongly agree.

\subsubsection{Distributive Justice}

This variable was assessed via 3-item scale based on three states of distributive justice prepositioned by Adams (1965): equality, positive inequality, and negative inequality. Respondents were requested to state whether what they receive from their job equals, exceeds, and under-rewards their contributions to their jobs. Their responses were assessed by a five-point Likert scale ranging from (1) Strongly disagree to (5) Strongly agree.

\subsubsection{Procedural Justice}

This variable was captured based on the six procedural rules theorized by Leventhal (1980) by asking the respondents to state whether the decision processes in their department embraced these rules: consistency, bias-suppression, accuracy, correctability, representativeness, and ethicality. Several researchers used Leventhal's (1980) rules (e.g. Schappe, 1998). A five-point Likert scale ranging from (1) Strongly disagree to (5) Strongly agree, was used to assess the degree to which respondents agree that these rules are applied regarding the process of decision making.

\subsubsection{Interactional Justice}

This variable was captured based on the six attributes pertaining to treatment and explanation practices theorized by Bies \& Moag (1986), including: honesty, avoiding deception, courtesy, respect for individual rights, propriety of behavior, and justifying decisions. A five-point Likert scale ranging from (1) Strongly disagree to (5) Strongly agree, was used to assess the extent which respondents agree that mangers' behavior with the employees reflect these attributes.

\subsubsection{Organizational Commitment}

Organizational commitment is captured in this study by a three-item scale of Brockner et al. (1992), which was developed based on the three dimensions of organizational commitment propositioned by Porter et al. (1974). A five-point Likert scale ranging from (1) Strongly disagree to (5) Strongly agree, was used to assess the responses.

\subsubsection{Job Satisfaction}

Job satisfaction is captured in this study via a 6-item scale presented by Agho et al. (1992) as a shortened version of the 18-item overall-job-satisfaction index developed by Brayfield and Rothe (1951). A five-point Likert scale ranging from (1) Strongly disagree to (5) Strongly agree, was used to assess the responses.

\section{Results of Data Analysis}

\subsection{Sample Description}

Participants ages varied between 25 and 62 with mean $=36.96$ and standard deviation $(\mathrm{SD})=6.967$. The number of male participants were 70 while female participant were 69 and 11 participants did not report their gender. The number of permanent employees who participated were 128 and those with annual contracts were17, whereas 5 participants did not report their employment type.

By using a $\chi^{2}$ test to compare the proportions of respondents and all employees according to their employment types, no significant difference between the two groups $\left(\chi^{2}=1.751 ; \mathrm{df}=1 ; \mathrm{p}=0.186\right)$ was present. Therefore, as "even a very high response rate is no guarantee against bias" (Oppenheim, 1992, p. 280), it can be clinched that there is a trivial possibility for non-response-bias apropos employment type.

As all concepts (variables) of this study are theory-laden and their measures are adapted from other studies, to confirm the belonging of each concept indicators to their corresponding variable to scrutinize the construct validity 
of each measurement (Carmines and Zeller, 1979); factor analyses are wrought. The requirement of using factor analysis are fulfilled in all variable (see Table 1) as cases-per-variables ratios are above 10-to-1, scores of Kaiser-Meyer-Olkin for sampling adequacy are between 0.702 (middling) and 0.865 (meritorious) (Kaiser, 1974), and results of Bartlett's test of sphericity were significant $(p<0.001)$.

Table 1. Factor analysis of the variables

\begin{tabular}{|c|c|c|c|c|c|c|c|}
\hline \multirow{2}{*}{$\begin{array}{l}\text { Variable/ } \\
\text { Indicator }\end{array}$} & \multicolumn{2}{|l|}{ Factor } & \multicolumn{4}{|c|}{$\begin{array}{l}\text { Barlett's Test of } \\
\text { sphericity }\end{array}$} & \multirow{2}{*}{$\begin{array}{l}\% \\
\text { variance }\end{array}$} \\
\hline & Loading & KMO & $\chi^{2}$ & $\mathrm{df}$ & $\mathrm{p}$ & Eigenvalue & \\
\hline Procedural Justice & & 0.86 & 715.18 & 15 & 0.000 & 4.521 & 75.347 \\
\hline 1 & 0.864 & & & & & & \\
\hline 2 & 0.898 & & & & & & \\
\hline 3 & 0.896 & & & & & & \\
\hline 4 & 0.822 & & & & & & \\
\hline 5 & 0.868 & & & & & & \\
\hline 6 & 0.858 & & & & & & \\
\hline Distributive Justice & & 0.727 & 202.27 & 3 & 0.000 & 2.39 & 79.674 \\
\hline 1 & 0.877 & & & & & & \\
\hline 2 & 0.916 & & & & & & \\
\hline 3 & 0.884 & & & & & & \\
\hline Interactional justice & & 0.853 & 877.23 & 15 & 0.000 & 4.852 & 80.865 \\
\hline 1 & 0.919 & & & & & & \\
\hline 2 & 0.902 & & & & & & \\
\hline 3 & 0.900 & & & & & & \\
\hline 4 & 0.918 & & & & & & \\
\hline 5 & 0.900 & & & & & & \\
\hline 6 & 0.855 & & & & & & \\
\hline Job Satisfaction & & 0.865 & 456.34 & 15 & 0.000 & 3.869 & 64.49 \\
\hline 1 & 0.857 & & & & & & \\
\hline 2 & 0.875 & & & & & & \\
\hline 3 & 0.874 & & & & & & \\
\hline 4 & 0.633 & & & & & & \\
\hline 5 & 0.756 & & & & & & \\
\hline 6 & 0.795 & & & & & & \\
\hline Organizational & & 702 & 158.7 & 3 & 0.000 & 2.254 & 75.141 \\
\hline 1 & 0.902 & & & & & & \\
\hline 2 & 0.844 & & & & & & \\
\hline 3 & 0.854 & & & & & & \\
\hline
\end{tabular}

$\mathrm{KMO}=$ Kaiser-Meyer-Olkin; $\mathrm{df}=$ degrees of freedom

\subsection{Reliabilities of Scales}

With exception to employees' intentions to leave their jobs for being captured by a single-item scale, reliabilities of scales utilized to capture the variables in this study were assessed via Cronbach's alpha that can be applied merely on multi-item scales. As Table 2 illustrates, the values of Cronbach's alpha vacillated between 0.845 that is regarded as very good, and 0.952 that is regarded as excellent (Hair et al., 2003). 
Table 2. Values of Cronbach's Alpha

\begin{tabular}{lll}
\hline Variables & Number of items & Cronbach's Alpha \\
\hline Job Satisfaction & 6 & .887 \\
Organizational Commitment & 3 & .833 \\
Distributive Justice & 3 & .872 \\
Procedural Justice & 6 & .934 \\
Interactional justice & 6 & .952 \\
\hline
\end{tabular}

As Table 3 demonstrates, the values and signs of Pearson correlation coefficients are consistent with previous research. Specifically, the signs of the correlations between intention to leave and the other variables are negative, while the signs of the correlations between predecessors of intention to leave are positive. Further, all the correlations were significant $(p<0.001)$.

Table 3. Pearson correlation coefficients between variables

\begin{tabular}{llllllll}
\hline Variables & Mean & $\mathrm{SD}$ & 1 & 2 & 3 & 4 & 5 \\
\hline Intention to leave job & 2.83 & 1.289 & & & & & \\
Job Satisfaction & 3.32 & 0.867 & -0.532 & & & & \\
Organizational Commitment & 3.73 & 0.914 & -0.520 & 0.748 & & & \\
Distributive Justice & 3.08 & 0.997 & -0.459 & 0.553 & 0.410 & & \\
Procedural Justice & 2.54 & 0.998 & -0.399 & 0.510 & 0.398 & 0.535 & \\
Interactional justice & 2.78 & 1.061 & -0.445 & 0.661 & 0.505 & 0.578 & 0.818
\end{tabular}

Note: SD refers to standard deviation, all the correlations were significant $(p<0.001)$

\subsection{Hypotheses Testing}

The mediation effects were tested according to the proposition of Baron \& Kenny (1986) as three regression equations were developed: the mediator on the independent, the dependent on the independent, and the independent on both the mediator and the independent. The mediation occurs when coefficient of the three regression are significant except the coefficient of the independent in the third equation, where if the coefficient equals zero indicates a complete mediation and its reduction indicate a partial mediation (Baron \& Kenny, 1986). The significances of the mediation effects are tested via the modus operandi proposed by Sobel (1982). The results of these three regression equations for each mediation effect are presented in Table 4.

Table 4. Results of testing mediation effects

\begin{tabular}{|c|c|c|c|c|c|c|c|c|c|}
\hline & & $\begin{array}{l}\text { regress } \\
\text { mediat } \\
\text { the } \\
\text { indepe }\end{array}$ & $\begin{array}{l}\text { ng the } \\
\text { or on } \\
\text { dent }\end{array}$ & $\begin{array}{l}\text { regress } \\
\text { depend } \\
\text { the } \\
\text { indeper }\end{array}$ & $\begin{array}{l}\text { ig the } \\
\text { nt on } \\
\text { dent }\end{array}$ & $\begin{array}{l}\text { regress } \\
\text { depend } \\
\text { the ind } \\
\text { and the }\end{array}$ & $\begin{array}{l}\text { g the } \\
\text { at on both } \\
\text { endent } \\
\text { nediator }\end{array}$ & \multicolumn{2}{|c|}{ Sobel's test } \\
\hline & & beta & $p$ & beta & $\mathrm{p}$ & beta & $\mathrm{P}$ & $Z$ & $\mathrm{p}$ \\
\hline Independent & $\begin{array}{l}\text { Distributive } \\
\text { Justice }\end{array}$ & 0.376 & 0.000 & -0.593 & 0.000 & -0.381 & 0.000 & \multirow{2}{*}{3.61} & \multirow{2}{*}{0.001} \\
\hline Mediator & $\begin{array}{l}\text { Organizational } \\
\text { Commitment }\end{array}$ & & & & & -0.562 & 0.000 & & \\
\hline
\end{tabular}




\begin{tabular}{|c|c|c|c|c|c|c|c|c|c|}
\hline Independent & $\begin{array}{l}\text { Procedural } \\
\text { Justice }\end{array}$ & 0.361 & 0.000 & -0.516 & 0.000 & -0.295 & 0.004 & \multirow{2}{*}{3.65} & \multirow{2}{*}{0.001} \\
\hline Mediator & $\begin{array}{l}\text { Organizational } \\
\text { Commitment }\end{array}$ & & & & & -0.605 & 0.000 & & \\
\hline Independent & $\begin{array}{l}\text { Interactional } \\
\text { justice }\end{array}$ & 0.365 & 0.000 & -0.541 & 0.000 & -0.298 & 0.004 & \multirow{2}{*}{3.84} & \multirow{2}{*}{0.000} \\
\hline Mediator & $\begin{array}{l}\text { Organizational } \\
\text { Commitment }\end{array}$ & & & & & -0.558 & 0.000 & & \\
\hline Independent & $\begin{array}{l}\text { Distributive } \\
\text { Justice }\end{array}$ & 0.481 & 0.000 & -0.593 & 0.000 & -0.306 & 0.007 & \multirow{2}{*}{3.95} & \multirow{2}{*}{0.000} \\
\hline Mediator & $\begin{array}{l}\text { Job } \\
\text { Satisfaction }\end{array}$ & & & & & -0.595 & 0.000 & & \\
\hline Independent & $\begin{array}{l}\text { Procedural } \\
\text { Justice }\end{array}$ & 0.443 & 0.000 & -0.516 & 0.000 & -0.223 & 0.043 & \multirow{2}{*}{4.12} & \multirow{2}{*}{0.000} \\
\hline Mediator & $\begin{array}{l}\text { Job } \\
\text { Satisfaction }\end{array}$ & & & & & -0.659 & 0.000 & & \\
\hline Independent & $\begin{array}{l}\text { Interactional } \\
\text { justice }\end{array}$ & 0.540 & 0.000 & -0.541 & 0.000 & -0.203 & 0.090 & \multirow{2}{*}{3.96} & \multirow{2}{*}{0.000} \\
\hline Mediator & $\begin{array}{l}\text { Job } \\
\text { Satisfaction }\end{array}$ & & & & & -0.627 & 0.000 & & \\
\hline
\end{tabular}

Note: the dependent refers to employees' intentions to leave their jobs; beta refers to variable coefficient in the regression equation.

The results of testing $\mathrm{H} 1$ through $\mathrm{H} 6$ presented in Table 4 reveal that the three conditions propositioned by Baron \& Kenny (1986) for the mediating effect are present. Pertaining to H1, the direct effect of distributive justice on organizational commitment is significant $(\mathrm{p}<0.001)$, and the direct effect of organizational commitment on intention to leave is significant $(p<0.001)$ in the presence of distributive justice with a reduction in the coefficient of distributive justice's direct effect on intention to leave implying a partial mediation. The result of Sobel's test $(\mathrm{z}=$ $3.61, \mathrm{p}<0.001)$ elucidates that organizational commitment significantly mediates the relationship between distributive justice and intention to leave; hence, $\mathrm{H} 1$ is accepted.

Pertaining to $\mathrm{H} 2$, the direct effect of procedural justice on organizational commitment is significant $(\mathrm{p}<0.001)$, and the direct effect of organizational commitment on intention to leave is significant $(p<0.001)$ in the presence of procedural justice and with a reduction in the coefficient of procedural justice's direct effect on intention to leave implying a partial mediation. The result of Sobel's test $(\mathrm{z}=3.65, \mathrm{p}<0.001)$ elucidates that organizational commitment significantly mediates the relationship between procedural justice and intention to leave; hence, $\mathrm{H} 2$ is accepted.

Pertaining to H3, the direct effect of interactional justice on organizational commitment is significant $(\mathrm{p}<0.001)$, and the direct effect of organizational commitment on intention to leave is significant $(p<0.001)$ in the presence of interactional justice and with a reduction in the coefficient of interactional justice's direct effect on intention to leave implying a partial mediation. The result of Sobel's test $(\mathrm{z}=3.84, \mathrm{p}<0.001)$ elucidates that organizational commitment significantly mediates the relationship between interactional justice and intention to leave; hence, $\mathrm{H} 3$ is accepted.

Pertaining to H4, the direct effect of distributive justice on job satisfaction is significant $(\mathrm{p}<0.001)$, and the direct effect of job satisfaction on intention to leave is significant $(p<0.001)$ in the presence of distributive justice with a reduction in the coefficient of distributive justice's direct effect on intention to leave implying a partial mediation. The result of Sobel's test $(z=3.61, p<0.001)$ elucidates that job satisfaction significantly mediates the relationship between distributive justice and intention to leave; hence, $\mathrm{H} 4$ is accepted.

Pertaining to H5, the direct effect of procedural justice on job satisfaction is significant $(p<0.001)$, and the direct effect of job satisfaction on intention to leave is significant $(\mathrm{p}<0.001)$ in the presence of procedural justice and with 
a reduction in the coefficient of procedural justice's direct effect on intention to leave implying a partial mediation. The result of Sobel's test $(z=3.65, p<0.001)$ elucidates that job satisfaction significantly mediates the relationship between procedural justice and intention to leave; hence, $\mathrm{H} 5$ is accepted.

Pertaining to H6, the direct effect of interactional justice on job satisfaction is significant $(\mathrm{p}<0.001)$, and the direct effect of job satisfaction on intention to leave is significant $(\mathrm{p}<0.001)$ in the presence of interactional justice and with a reduction in the coefficient of interactional justice's direct effect on intention to leave implying a partial mediation. The result of Sobel's test $(\mathrm{z}=3.84, \mathrm{p}<0.001)$ elucidates that job satisfaction significantly mediates the relationship between interactional justice and intention to leave; hence, $\mathrm{H} 6$ is accepted.

\section{Discussion and Conclusion}

The results of the three regression equations used for testing each hypothesis are coherent with previous research, i.e. each relation in these regressions was as predicted. Specifically, distributive justice, procedural justice, and interactional justice positively influence organizational commitment $(b=0.376,0.361,0.365$, respectively) and job satisfaction $(b=0.481,0.443,0540$, respectively), and negatively influence intention to leave $(b=-0.593,-0.516$, -0.541 , respectively), as b demonstrate the influence magnitude. Hence, accepting the hypotheses in this study is congruent with previous research; notwithstanding, they present a new knowledge through corroborating the plausible sequence for the effects of the antecedents of intention to leave, as the partial mediation was endorsed. The results of this study substantiated the partial mediation effects for both organizational commitment and job satisfaction on the relationships between the three facets of organizational justice and intention to leave, which accentuates the importance of the two mediators in predicting and alleviating employees' intentions to leave. The partial mediation implies that organizational justice influences employees' intentions to leave their job a part from the mediators. Further, the importance of the three facets of organizational justice in predicting and controlling the mediating variables is also emphasized.

To maintain low rate of employees' turnover, mangers are advised to enhance employees' perceptions of the three facets of organizational justice, which represent that first stage of managing employees' retention. As the three aspects of organizational justice have effects on employees' satisfaction with their jobs and their commitment to their workplace, managers are advised to monitor these two attitudes, which represent the second stage of managing employees' retention. The third stage of managing employees' retention is monitoring employees' intention to leave, which have effects on their actual turnover.

As the relations between the studied variable were evident in several context, the supported mediating roles can be examined in different contexts. In addition, a further exploration for the antecedents of organizational justice is recommended.

\section{Limitation of This Study}

Although this study targeted all the employees in the studied department and achieved an acceptable response rate, the number of respondent is relatively small compared to the whole population, i.e. all the employees of governmental department. Though the generalizability across different governmental departments is plausible, generalizing these results across different sectors should be done with prudence.

\section{References}

Adams, J.S. (1965). Inequity in social exchange. In Leonard Berkowitz (Ed.), Advances in Experimental Social Psychology (Vol. 2, pp. 267-299). London: Academic Press. https://doi.org/10.1016/s0065-2601(08)60108-2

Agho, A.O., Price, J.L., \& Mueller, C.W. (1992). Discriminant validity of measures of job satisfaction, positive affectivity and negative affectivity. Journal of Occupational and Organizational Psychology, 65(3), 185-196. https://doi.org/10.1111/j.2044-8325.1992.tb00496.x

Allen, N.J., \& Meyer, J.P. (1990). The measurement and antecedents of affective, continuance and normative commitment to the organization. Journal of Occupational Psychology, 63, 1-18. https://doi.org/10.1111/j.2044-8325.1990.tb00506.x

Baron, R.M., \& Kenny, D.A. (1986). The Moderator-Mediator Variable Distinction in Social Psychological Research: Conceptual, Strategic, and Statistical Considerations. Journal of Personality and Social Psychology, 51(6), 1173-1182. https://doi.org/10.1037/0022-3514.51.6.1173

Basar, U., \& Sigri, U. (2015). Effects of teachers' organizational justice perception on intention to quit: mediation role of organizational identification. Educational Sciences: Theory \& Practice, 15(1), 45-59. https://doi.org/10.12738/estp.2015.1.2326 
Bies, R.J., \& Moag, J.S. (1986). Interactional justice: communication criteria of fairness. In Roy Lewicki, Blair H. Shepard and Max H. Bazerman (Eds.), Research on Negotiation in Organizations (Vol. 1, pp. 43-55). Greenwich: JAI Press.

Bies, R.J., \& Shapiro, D.L. (1988). Voice and justification: their influence on procedural fairness judgment. Academy of management Journal, 31(3), 676-685. https://doi.org/10.2307/256465

Brayfield, A.H., \& Rothe, H.F. (1951). An index of job satisfaction. Journal of applied Psychology, 35(5), 307-311. https://doi.org/10.1037/h0055617

Brockner, J., \& Siegel, P. (1996). Understanding the interaction between procedural and distributive justice: the role of trust. In Roderick M. Kramer and Tom R. Tyler (Eds.), Trust in Organizations: Frontiers of Theory and Research (pp. 390-413) Thousand Oaks: Sage Publications. https://doi.org/10.4135/9781452243610.n18

Brockner, J., Tyler, T.R., \& Cooper-Schneider, R. (1992). The influence of prior commitment to an institution on reactions to perceived fairness: the higher they are, the harder they fall. Administrative Science Quarterly, 37(2), 241-261. https://doi.org/10.2307/2393223

Buchanan II, B. (1974). Building organizational commitment: the socialization of managers in work organizations. Administrative Science Quarterly, 19(4), 533-546. https://doi.org/10.2307/2391809

Byrne, Z.S., \& Cropanzano, R. (2001). The history of organizational justice: the founders speak. In R. Cropanzano (Ed.), Justice in Workplace: From Theory to Practice (pp. 3-26). New Jersey: Lawrence Erlbaum Associates.

Carmines, E.G., \& Zeller, R.A. (1979). Reliability and Validity Assessment. Thousand Oaks, CA: SAGE Publications, Inc. https://doi.org/10.4135/9781412985642

Cheng, S.Y. (2014). The mediating role of organizational justice on the relationship between administrative performance appraisal practices and organizational commitment. The International Journal of Human Resource Management, 25(8), 1131-1141. https://doi.org/10.1080/09585192.2013.816864

Cook, J., \& Wall, T. (1980). New work attitude measures of trust, organizational commitment and personal need $\begin{array}{llll}\text { non-fulfilment. Journal of } & \text { Occupational }\end{array}$ https://doi.org/10.1111/j.2044-8325.1980.tb00005.x

Das, D., Nandialath, A., \&Mohan, R. (2013). Feeling unsure: quit or stay? Uncovering heterogeneity in employees' intention to leave in Indian call centers. The International Journal of Human Resource Management, 24(1), 15-34. https://doi.org/10.1080/09585192.2012.665067

Deutsch, M. (1975). Equity, equality, and need: what determines which value will be used as the basis of distributive justice?. Journal of Social Issues, 31(3), 137-149. https://doi.org/10.1111/j.1540-4560.1975.tb01000.x

Folger, R., \& Cropanzano, R. (1998). Organizational Justice and Human Resource Management. Thousand Oaks: Sage Publications.

Folger, R., \& Greenberg, J. (1985). Procedural justice: an interpretive analysis of personnel system. In K. M. Rowland and G. M. Ferris (Eds.), Research in Personnel and Human Resource Management (Vol. 3, pp. 141-183). Greenwich: JAI Press.

Garcia-Chas, R., Neira-Fontela, E., \& Castro-Casal, C. (2014). High-performance work system and intention to leave: a mediation model. The International Journal of Human Resource Management, 25(3), 367-389. https://doi.org/10.1080/09585192.2013.789441

Greenberg, J. (1987). A taxonomy of organizational justice theories. Academy of Management Review, 12(1), 9-22.

Greenberg, J. (1990). Organizational justice: yesterday, today, and tomorrow. Journal of Management, 16(2), 399-432. https://doi.org/10.1177/014920639001600208

Hair, J.F., Babin, B., Money, A.H., \& Samouel, P. (2003). Essentials of Business Research. New York: Wiley.

Hassan, A., \& Hashim, J. (2011). Role of organizational justice in determining work outcomes of national and expatriate academic staff in Malaysia. International Journal of Commerce and Management, 21(1), 82-93. https://doi.org/10.1108/10569211111111711

Homans, G.C. (1961). Social Behaviour: Its Elementary Forms. London: Routledge and Kegan Paul.

Hussein, S., Moriarty, J., Stevens, M., Sharpe, E., \& Manthorpe, J. (2014). Organisational factors, job satisfaction and intention to leave among qualified social workers in England. Social Work Education, 33(3), 381-396. 
https://doi.org/10.1080/02615479.2013.806467

Kaiser, H.F. (1974). An index of factorial simplicity. Psychometrika, 39(1), 31-36. https://doi.org/10.1007/BF02291575

Leventhal, G.S. (1980). What should be done with equity theory?: new approach to the study of fairness in social relationships. In K. J. Gergen, M. S. Greenberg and R. H. Weiss (Eds.), Social Exchange: Advances in Theory and Research (pp. 27-55.) New York: Plenum. https://doi.org/10.1007/978-1-4613-3087-5 2

Locke, E.A. (1976). The nature causes and causes of job satisfaction. In M.C. Dunnette (Ed.). Handbook of industrial and organisational psychology (pp. 1297-1349). Chicago: Rand McNally.

Nakra, R. (2014). Understanding the impact of organizational justice on organizational commitment and projected job stay among employees of the business process outsourcing sector in India. Vision, 18(3), 185-194. https://doi.org/10.1177/0972262914539217

Nowakowski, J.M., \& Conlon, D.E. (2005). Organizational justice: looking back, looking forward. The International Journal of Conflict Management, 16(1), 4-29. https://doi.org/10.1108/eb022921

Oppenheim, A.N. (1992). Questionnaire design, Interviewing and Attitude Measurement. London: Pinter.

Porter, L.W., Steers, R.M., Mowday, R.T., \& Boulian, P.V. (1974). Organizational commitment, job satisfaction and turnover among psychiatric technicians. Journal of Applied Psychology, 59(5), 603-609. https://doi.org/10.1037/h0037335

Schappe, S.P. (1998). Understanding employee job satisfaction: The importance of procedural and distributive justice. Journal of Business and Psychology, 12(4), 493-503. https://doi.org/10.1023/A:1025007307058

Sia, L.A., \& Tan, T.A.G. (2016). The influence of organizational justice on job satisfaction in a hotel setting. Business \& Economics Review, 26(1), 17-29.

Sobel, M.E. (1982). Asymptotic Confidence Interval for Indirect Effect in Structural Equation Models. Sociology Methodology, 13, 290-312. https://doi.org/10.2307/270723

Taber, T.D., \& Alliger, G.M. (1995). A task-level assessment of job satisfaction. Journal of Organizational Behavior. 16, 101-121. https://doi.org/10.1002/job.4030160202

Thibaut, J., \& Walker, L. (1978). A theory of procedure. California Law Review, 66(3). 541-566. https://doi.org/10.2307/3480099

Velde, M.E.G. van der, \& Feij, J.A. (1995). Change of work perception and work outcomes as a result of voluntary and involuntary job change. Journal of Occupational and Organizational Psychology, 68, 273-290. https://doi.org/10.1111/j.2044-8325.1995.tb00587.x

Xerri, M.J. (2014), Examining the relationship between organisational justice, job satisfaction and the innovative behavior of nursing employees. International Journal of Innovative Management, 18(1), 1-22. https://doi.org/10.1142/S1363919614500042

Yurchisin, J., \& Park, J. (2010). Effects of Retail Store Image Attractiveness and Self-Evaluated Job Performance on Employee Retention. Journal of Business Psychology, 25, 441-450. https://doi.org/10.1007/s10869-010-9161-x 